\title{
Cooperation With Kopassus? Take Care!
}

\begin{abstract}
Allan Behm
$\mathrm{H}$ e who sups with the devil had better have a long handled spoon. Given the nature of Special Forces, their lethal capabilities and their suitability for both disavowable and covert operations, the decision to develop cooperative relationships between such forces at the international level presents governments with a kind of 'Hobson's choice'. Governments must either accept any or all of the consequences of such cooperation, or resist the demands for such cooperation totally. The choice turns around one fundamental issue: are the controls on Special Forces and their capabilities by their own government and its military commanders sufficiently strong to ensure that there could be no para-legal or illegal use of such forces, either domestically or internationally?

In considering operational relationships between Australia's Special Air Service Regiment (SASR) and Indonesia's Special Forces (Kopassus), the effectiveness of Indonesia's command and control arrangements is a cardinal issue. For any Australian government, cooperation with Indonesia's special forces (Kopassus) raises three additional questions:
\end{abstract}

- What are the benefits of such cooperation to Australia?

- What are the benefits of such cooperation to Indonesia?

- Does such cooperation in any way prejudice the longer-term bilateral relationship?

The answer to each of these questions demands the exercise of fine judgment on the part of ministers and their advisers.

\section{Some Historical Background}

For Indonesia, the Special Forces, under their various historical guises, have carved out for themselves a leadership position in the Armed Forces

Indonesia began to acquire the rudiments of Special Force skills in the late 50 s and early 60 s when, in their 'zero sum game' competition for global strategic influence, the Soviet Union and the USA sought to balance each other in the socalled third world. While the Soviet Union provided Indonesia with defence aid in

Allan Behm was formerly head of the International Policy and Strategy Divisions of the Department of Defence (1996-2001) and the South East Asia Branch (1983-85), responsible, inter alia, for managing the defence relationship with Indonesia. He speaks Indonesian and Malay, and has dealt extensively with the Indonesian armed forces officers mentioned in this paper. He is now a director of Knowledge Pond, an international group that advises on political risk and strategy. 
the form of warships and combat fighters, the USA focused more on military training and officer education. Under the guidance of the US Defence Attaché in Jakarta, Colonel George Benson, the USA embarked on an officer education program that eventually saw hundreds trained in the USA, many at Fort Leavenworth, the US Army's Combined Arms Center in Kansas, where they acquired the taste for 'ranger' capabilities. While the USA provided relatively little direct Special Forces training, the Indonesian army established its elite Kopassus units, and developed training programs modelled on those of the USA. By the mid 1960s Indonesia was able to mount covert operations using its embryonic special forces.

The SASR and Kopassus have enjoyed (if that is the word!) an on-again-offagain relationship for over 40 years. Their first substantive contact occurred during konfrontasi (1963-65). Indonesian Special Forces and Indonesian irregulars conducted raids in Borneo, Singapore and Peninsular Malaysia in an attempt to destabilize the federation and to undermine what President Sukarno saw as the continuation of British colonial influence in the region. Australian and British SAS patrols were more than a match for their Indonesian counterparts, and registered a number of tactical successes against them.

The downfall of President Sukarno, and the emergence of Lt Gen Soeharto (one of the few among his peers who had not been educated in the USA) in the aftermath of the coup attempt of 30 September 1965, put an end to konfrontasi, saw Indonesia recognize the Federation of Malaysia in 1966, and set up the preconditions for the first tentative moves towards establishing defence-defence relations between Australia and Indonesia. By the mid-70s, Australia and Indonesia had established a substantial and diverse defence cooperation program. During the subsequent decade, the defence cooperation program funded the transfer of some 23 ex-RAAF Sabre fighters and seven Attack-class patrol boats to Indonesia, and some tentative links between the Special Forces of the two countries that were largely confined to unit-level visit exchanges, long range patrol training, and some special training in counter-terrorist and counter-hijack skills.

The publication of a detailed exposé of the Soeharto family's financial empire, President Soeharto's cronyism and the parallels between Soeharto and Philippines President Marcos in The Sydney Morning Herald in April 1986 brought the defence cooperation program to a grinding halt. During the early $90 \mathrm{~s}$, however, the defence relationship resumed, tentatively at first, then accelerating after 1993 to the point where Australia and Indonesia were able to conduct a major bilateral military conference at the senior command level in March 1999. Cooperation between the SASR and Kopassus was reinstated in 1993, though it was restricted to senior officer visits (President Soeharto's son-in-law, Prabowo Sugianto, who enjoyed near iconic status in Kopassus, visited Australia several times), the participation by Kopassus elements in two bilateral exercises in northern Australia, and Australian-provided training in counter-hijack techniques.

Both the Keating and Howard governments sanctioned this cooperation for three main reasons: 
- $\quad$ to assess the ability of Kopassus to manage and resolve any terrorist incident directed against Australians in Indonesia, Australian diplomatic personnel, the Australian Embassy, and Qantas aircraft and assets in Jakarta and Denpasar;

- $\quad$ to ensure that Kopassus had the necessary military skills to manage counter hijack operations; and,

- given the status of Kopassus within the Indonesian military, to improve links and contacts at the senior command level - indeed, at that time it was impossible to deal with the Indonesian Armed Forces without dealing with Kopassus officers.

Of course, ministers such as Robert Ray, Ian MacLachlan and John Moore were well aware of the appalling record of Kopassus elements in Indonesia and in East Timor. They seriously questioned the value of links with Kopassus, but came to the view that the safety of Australians was the higher consideration, and that cooperation should be limited to those activities that bore directly on that objective. But it was no easy decision for government to establish and maintain Special Forces links with an organization, elements of which operated outside the boundaries of both Indonesian and international law.

This pragmatic position reflected the fact, well understood by Australian ministers, that Kopassus was under the direct control of the chief of the Indonesian defence force and, for that matter, of President Soeharto. Australian Governments were sensitive to the abuse of power characteristic of the Soeharto regime and its instrumentalities, but maintained links with Kopassus for the practical reason of managing the bilateral relationship as effectively as possible and ensuring the safety of Australian diplomats, business people and travellers, and to enable the preservation of some measure of effective dealing with a key national institution, the Armed Forces.

\section{What is Different Now?}

During the early months of 1999 , as it became progressively clearer that East Timor was to become the focal point of a law and order crisis, there was growing circumstantial evidence that Kopassus elements were both arming and training the militias that were soon to turn Dili into an inferno. Although the Australian intelligence agencies could not find the 'smoking gun' that would decisively incriminate Kopassus or the Indonesian High Command, in early June 1999 the Australian government directed the then vice chief of the defence force, Air Marshal Doug Riding, accompanied by this writer, to visit the headquarters of the Indonesian Armed Forces in Jakarta to discuss the issue, and to warn the senior leadership of the consequences of Kopassus dealings with the militias. ${ }^{1}$

1 The author prepared the Aide Memoire on which Air Marshal Riding based his discussions with General Wiranto in June 1999, and was present at the meeting. 
Air Marshal Riding was received politely, and Generals Susilo Bambang Yudhoyono (chief of territorial affairs) and Sugiono (the vice chief of the Indonesian defence force, also a Fort Leavenworth graduate) and their aides listened attentively to Riding's careful, detailed and coolly delivered account of the growing ferocity of the militias, the apparent inability of the Indonesian armed forces in East Timor to control them, and the need for the Indonesian headquarters to rein in the Special Forces assisting the militias. Nothing happened. For the fact seemed to have been that the Indonesian chief of the defence force was not able, or did not wish, to exercise his command over the 'independent' (or 'rogue') elements within Kopassus. Those elements had their own agenda, which was both to destabilize East Timor and, more dangerously, undermine the authority of President Habibie. The alleged involvement of Kopassus elements in fomenting racial and religious strife in Kalimantan, Sulawesi, Aceh and Ambon, and their likely involvement in the killing of two American nationals near the Freeport mine in West Papua in August 2002, suggest that Kopassus is no more under the effective control of General Sutarto now than it was under the control of General Wiranto.

Terrorism has become an endemic feature of Indonesian politics assassinations in West Papua, bombings in Aceh, arson in Sulawesi, aggravated assault and rape in Kalimantan. Abuses of human rights are nothing more than forms of terrorism. And it is not coordinated terrorism conducted by a single group, but the random and temporary coalescence of competing groups united only in the use of violence - Muslims against Muslims in Aceh, Muslims against Christians in Sulawesi, and indigenous people against Javanese in West Papua. In other words, terror is the tool of anarchic elements that can find no other means of expressing their opposition than through violence. Terror is, after all, the power of the impotent. There is widespread concern both in Indonesia and internationally that Kopassus elements provide material and moral support to some of the more violent of these groups, especially those who seek to misuse the concept of jihad to justify the use of violence against Christians and ethnic Chinese citizens, as well as the various Islamic groups that are more pluralist and tolerant than those identified with the Madrasah fundamentalist schools, such as the school headed by Abu Bakar Bashir, who is currently suspected of master-minding the violence that culminated in the Bali bombings.

As a core part of the larger Indonesian Armed Forces, Kopassus supports the general approach of the Armed Forces leadership to issues of national security, including their opposition to both the balkanization of Indonesia or the formation of an Islamic state. But the problem is that some elements of Kopassus, whether through association with elements of the Soeharto family or for their own private motives, are evidently not under the control of Indonesia's military leadership. These Kopassus elements appear to have a confused mix of motives for supporting the various Islamic groups that favour the use of violence. Those motives vary from place to place, but would appear to include: 
- $\quad$ a wish to support anarchical behaviour for a range of narrow and short-term reasons, including personal advantage;

- a belief that non-Islamic groups profiteer at the expense of Muslims, requiring a more effective and immediate redistribution of wealth than is currently in place;

- a wish to reinforce local identity between Kopassus 'heroes' and local youths;

- a wish to destabilize the government of President Megawati Sukarnoputri; and

- a wish to reposition Kopassus as the main winner should the Indonesian military take on a larger role in the government of Indonesia.

None of these motives offers any confidence that Kopassus is effectively led and managed by the current senior leadership in the Indonesian military headquarters.

But more disturbing than the apparent meddling by Kopassus in the violence that now characterizes so much of Indonesia's political climate is the ability of Kopassus to interfere directly in the workings of the government of Indonesia itself. Kopassus is, in some respects, a law unto itself, able to use its relatively advanced capabilities in the use of armed force as and when it sees fit. Dominating the Indonesian command chain as it does, Kopassus is well able to employ the very specific skills it might learn or reinforce from Australia against its own government. And therein lies the greatest danger to Australia from the provision of Special Forces training.

\section{Where to now?}

The Bali bombings of 12 October 2002 have brought into even sharper focus the desperate situation in which Indonesia currently finds itself. At this point in its political evolution, Indonesia appears to be facing a double jeopardy: fragmentation into a number of economically weak and unstable mini-states (balkanisation), or the re-imposition of Jakarta's authority by the Indonesian military (martial law). Neither is good for Australia.

Australia has real interests at stake in the stability and security of Indonesia. But Australia appears to be oblivious to the consequences of collapse in Indonesia, and to the consequences of its own inaction. The balkanisation of Indonesia would present Australia with the terrible prospect of a procession of East Timortype operations, quite possibly simultaneously. And the imposition of military rule would reverse progress towards democracy and representative government that is the bedrock of stability, security and prosperity.

Either way, the economic costs would be high. Peacekeeping operations such as East Timor cost about $\$ 1.5$ billion in total additional costs, and that does not include the follow-up aid programs on which local security depends. The imposition of martial law or some form of military dictatorship brings with it a retreat from the normal means of conducting international relations, and would impose on Australia additional (and substantial) defence costs. Both outcomes 
effectively constrain the options available to future Australian governments to invest budget funds on our own social and infrastructural development. The more significant impact, however, is on the region's long-term strategic stability and Australia's security. If that really matters, then Australia cannot continue to stand by and watch.

In the management of strategic relationships, action does not guarantee success. But inaction certainly courts failure. So, what can Australia do? Given that Australia spent around $\$ 1$ billion to secure itself against illegal immigrants in flimsy boats, investing less than one hundredth of that would provide significant avenues for assisting Indonesia to control and reverse its current descent into chaos.

While they are beyond the scope of this paper, there are many things that Australia could do other than to rely on renewed relations with Kopassus to define the future. They include:

- working to strengthen Indonesia's political institutions by building public, high-level and frequent links between our respective Parliaments;

- helping Indonesia reconstruct its legal and judicial system;

- helping Indonesia to eradicate corruption in its public administration through the introduction of legislation and codes of practice based on ethics rather than venality;

- working with Indonesia to improve the effectiveness of its law enforcement services through enhanced training and professional development, especially at the senior leadership level;

- cooperating with Indonesia to develop its free-enterprise institutions by supporting links between the respective business councils, chambers of commerce, chambers of manufacturers, banking associations and insurance councils, since a sound economy is the best defence against the popular disaffection that breeds terrorism;

- developing our own understanding of Indonesia and its culture and accept that Islam is not an ideology that advocates and maintains terrorism and violence, but rather a religion that encourages individual Muslims to live in harmony; and

- re-engaging with the Indonesian Armed Forces but at this time, only in the areas of high-level dialogue to build confidence and an acceptance of the rightful place of the military in a civil society, and professional development to reinforce that acceptance.

Dealings with Special Forces should await much clearer indications that they are under the full and effective control of the Indonesian military leadership and, more importantly, the elected Indonesian government.

The writer acknowledges the constructive comments provided by a number of senior ADF officers, both serving and retired, including Air Marshal Riding. 